\title{
The impact of inflation on stock market performance in Nigeria ${ }^{1}$ Daferighe, Emmanuel E. B.Sc; MBA (Benin), M.Sc; ACA and ${ }^{2}$ Charlie, Samuel Sunday B.Sc; MBA, CNA
}

\author{
${ }^{1} \mathrm{Ph} . \mathrm{D}$. Candidate at the University of Benin, Nigeria, Lecturer, Department of Accounting, \\ University of Uyo, Nigeria, daferighe2e@yahoo.com \\ Director, Centre for Social and Environmental Accounting (CSEAR), Nigeria, \\ ${ }^{2}$ Ph.D. Candidate at the University of Uyo, Nigeria, Lecturer, Department of Accounting, \\ University of Uyo, Nigeria, owocharlie@yahoo.com
}

\begin{abstract}
The stock market is an economic institution that promotes the growth and development of the economy of a nation. This paper investigated the impact of inflation on stock market performance in Nigeria using time series data for twenty years from 1991 -2010. The regression analysis was used to evaluate the influence of inflation on various measures of stock market performance; market capitalization (MCAGDP), total value traded ratio (TVMS), percentage change in All-share Index (\% $\% \mathrm{ASI})$ and turnover ratio (TOR). It was revealed that these measures were negatively related to inflation in convergence to a priori expectation except for TOR which showed a positive relationship. This seemly low level of influence of inflation ranging between $14.6 \%$ and $0.3 \%$ revealed that stock market investments are regarded as a good hedge against inflation in Nigeria. However, the Securities and Exchange Commission (SEC) and the Nigerian Stock Exchange (NSE) should engage in public enlightenment and improve on corporate governance framework to encourage more investment and improve transactions in the market considering its present low level of activities. It was recommended that the Central Bank of Nigeria (CBN) should formulate and use policy statements that will maintain inflation at low ebb in order not to erode the value of gains by investors on stock.
\end{abstract}

Key Words: stock market performance, inflation, regression model, economic development

\section{INTRODUCTION}

The stock market is a common feature of a modern economy and it is reputed to perform functions that promote the growth and development of the economy. The market is an economic institution; which promotes efficiency in capital formation and allocation. It enables governments and industry to raise long-term capital for financing new projects, and expanding and modernizing industrial and commercial concerns.

Investment in the stock market is long term in nature; hence any development that could affect the stability of the polity or economy usually has serious impact on the performance of the stock market. Corrado and Jordan (2002) identify inflationary rate amongst others as a factor that could influence the market performance.

Economists have long recognized inflation as one of the major factors that could derail the economy of any country. In Nigeria, the problem of inflation has caused the monetary authority to seek remedies on a continual basis. Therefore, studying the impact of macroeconomic factors such as the rate of inflation on stock market performance has implications for investors and policy makers.

The stock market performance influences the performance of the economy vice versa. According to Alile (1997), the central objective of the stock exchange worldwide remains the maintenance of the efficient market with attendant benefit of economic growth.

In recent times there was a growing concern on the role of stock market in economic growth (Levine and Zervos, 1996; Demirguc-Kunt and Levine, 1996; Oyejide, 1994; Nyong, 1997; Obadan, 1998; Onosode, 1998; Emenuga, 1998; Osinubi, 1998). The stock market is of interest to economists and policy makers because of the perceived benefits to the economy. 
Studies by Corrado and Jordan (2002); Onagoruwa (2006); Daferighe and Aje (2009) look at some of the factors influencing stock market price behaviour. The stock market serves as a veritable tool in the mobilization and allocation of savings among competing uses which are critical to the growth and efficiency of the economy.

The performance of the stock market is of utmost importance to investors, policy makers and the likes. The measures of stock market performance include market capitalization; which measures stock market size, stock market liquidity which refers to the ability of investors to buy and sell securities easily. Others are All Share Index; which reflects the performance and condition of the stock market, and the turnover ratio; which is an index of comparison for market liquidity rating and level of transaction costs.

In Nigeria, inflation rates have persistently been two digits; this has been an issue confronting policy makers, investors, analysts and economists. It is one of the major factors that could derail the economy of any nation. The stock market which also contributes to economic growth will invariably be affected by inflation, hence the need for this paper.

In the paper the issues for determination are as follows:

(i) what is the correlation between inflation and the total value of listed shares in the Nigerian stock market?

(ii) is there any correlation between stock market liquidity and inflation?

(iii) does inflation impact positively on the performance and condition of the stock market?

(iv) what is the correlation between inflation and the turnover ratio of the Nigerian stock market?

Studies by DeGregorio (1992); Fischer (1993); Barro (1995); and Bruno and Easterly (1995) uncover a significant negative correlation between inflation and the growth performance of various economies. This paper investigates the empirical association between inflation and the performance of the stock market in Nigeria; to establish statistical association between inflation and various stock market performance measures. Evidence regarding this relationship in Nigeria seems scarce in the literature. It is in the light of this that the detailed nature of the empirical linkages between inflation and the various measures of stock market performance in Nigeria is being undertaken.
Methodology and Model Specification: This paper uses time series data for a period of twenty (20) years from 1991 to 2010 . The population of the study is all companies listed on the Nigerian Stock Exchange (NSE).

The measures of stock market performance are:

(i) Market capitalization ratio(MCAGDP) which is the market capitalization divided by the Gross Domestic Product (GDP).

(ii) Total value of shares traded ratio (TVMS) which is the total value of share traded divided by the GDP.

(iii) Percentage change in All Share Index which is represented by ( $\% \Delta A S I)$.

(iv) Turnover ratio (TOR) which is the total value of shares traded divided by the market capitalization.

The following models are formulated for this study:

$$
\begin{aligned}
& \text { MCAGDP }=\alpha_{0}+\alpha_{1} \text { INF }+\mu---------\quad \text { Model } 1 \\
& \text { TVMS } \quad=\beta_{0}+\beta_{1} \text { INF }+ \text { e--------------Model } 11 \\
& \% \Delta \text { ASI. }=\theta_{0}+\theta_{1} \text { INF }+\gamma----------\quad \text { Model } 111 \\
& \text { TOR } \quad=\rho_{0}+\rho_{1} \text { INF+ }+\varepsilon------\quad \text { Model IV }
\end{aligned}
$$

INF = Inflation Rate

$\alpha_{0}, \beta_{0}, \theta_{0}, \rho_{0}=$ Constants of the models

$\mu, e, \gamma, \varepsilon=$ stochastic variables or error terms.

$\alpha_{1}, \beta_{1}, \theta_{1}, \rho_{1}=$ Coefficients of the models

In principle, the a priori expectation is that the stock market should do well under conditions of strong economic growth and low inflation rates. Thus:

\begin{tabular}{cc}
$\delta$ MCAGDP & \\
\hdashline$\delta$ INF & $>0$ \\
$\delta$ TVMS & \\
\hline$\delta$ INF & $>0$ \\
$\delta \% \triangle A S I$. & \\
\hline$\delta$ INF & $>0$ \\
$\delta$ TOR & \\
$-\bar{O}$ INF & $>0$
\end{tabular}

The basic assumption for this work is thus; 
$\mathrm{H}_{0}$ : There is no negative statistical association between stock market performance measures of the Nigerian stock market and inflation.

The data; mainly secondary data; were organized and analyzed by the statistical SPSS package to determine the relationship between inflation and the stock market performance measures and to determine the extent of dependence between inflation rate and the stock market measures. The student t-statistic was used to test the hypothesis at $5 \%$ level of significance.

Stock market contributes to economic growth through specific services it performs either directly or indirectly. Among the functions of the stock market are mobilization of savings, creation of liquidity, risk diversification, improved dissemination and acquisition of information, and enhanced incentive for corporate control.

At any stage of a nation's development, both the government and the private sectors would require long term capital. Companies would need to build new factories, expand existing ones, or buy new machinery. On the other hand, government would require funds for the provision of infrastructures. All these activities require long term capital; which is provided by a well-functioning stock market.

Various researches seem to show convergence opinions on the impact of inflation on the stock market. Engle and Rangel (2005) studied emerging markets as well as developed markets by accounting for volatility clustering and find that countries with high rates of inflation tend to have high stock market volatility.

On their part, Boyd, Levine and Smith (1996) in their study conclude that inflation is negatively correlated with stock market performance. Others that share this opinion include Hellerstein (1997); Hamilton (2005); Skousen (2006); Caban (2008); Gottlieb (2010).

Gerolamo (2001) identifies the impact of inflation on interest rate as a channel through which it affects the stock market and ultimately economic growth. In studying the impact of Real Gross Domestic Product (RGDP), inflation and interest rates on stock prices of quoted companies in Nigeria, Daferighe and Aje (2009) conclude that inflation and interest rates are negatively correlated with stock prices.

The determination of the overall growth of an economy depends on how efficiently the stock market performs its allocative functions of capital. The main measures of stock market performance include; stock market indexing, market capitalization and stock turnover.

Stock market indexing is one of the most widely used measures of stock performance. Investors hold portfolios of many assets but it is cumbersome to follow progress on each security in the portfolio. Thus, it is prudent to observe the entire market under the notion that their portfolio moved in the same direction as the aggregate market. According to Simiyu (1992) as cited in Kithinji and Ngugi (2009), the assumption that randomly selecting a large number of stocks from the total market should enable the investor to generate a rate of return comparable to the market.

Market capitalization is another measure of stock market performance. It measures market movements by measuring the total value of stock in a particular stock market by aggregating the market value of the quoted stocks. Changes in market capitalization occur due to fluctuations in share prices or issuance of new shares and bonus issues. The implication is that increased level of activity at the market may signal more investments in the market.

On the other hand, market turnover indicates inflows and outflows in the stock market and it is based on the actively traded shares. Otuke (2006) cited in Kithinji and Ngugi (2009) states that a change occurs due to the actively traded shares and owing to fluctuations in share prices or number of shares traded in a given day.

Inflation affects the performance of stock markets as it causes differences between real and nominal interests rates; thus changing the spending and saving behaviour of individuals, companies and government. Unexpected changes in the rate of inflation make it difficult for companies to plan; which inhibits growth and innovations. Beyond the impact of the domestic economy, differential inflation and interest rates influence the traded balance between countries and exchange rate of currencies (Reilly and Brown, 1997).

Data Presentation and Result of Analysis: Table 1A presents data for Inflation rates, market capitalization ration, value traded ratio, turnover ratio and percentage change in All-share index (ASI) for 1991 to 2010 . The results of the evaluation of the regression models are presented as follows: 
Table1A: Inflation rate, market capitalization ratio, value traded ratio, turnover ratio and percentage change in Allshare Index (1991-2010).

\begin{tabular}{|c|c|c|c|c|c|c|c|c|c|}
\hline Year & $\begin{array}{l}\text { Infation } \\
\text { rate } \\
\text { (INF) (1) }\end{array}$ & $\begin{array}{l}\text { Market } \\
\text { capitalization } \\
\text { N'billon (2) }\end{array}$ & $\begin{array}{l}\text { Gross } \\
\text { Domestic } \\
\text { Product at } \\
\text { current } \\
\text { price } \\
\text { N'billon } \\
\text { (3) }\end{array}$ & $\begin{array}{l}\text { Market } \\
\text { capitalization } \\
\text { ratio } \\
(\text { MCAGDP) } \\
(4=2 / 3)^{\star *}\end{array}$ & $\begin{array}{l}\text { Value of } \\
\text { Domestic } \\
\text { share } \\
\text { traded } \\
\text { N'billon } \\
\text { (5) }\end{array}$ & $\begin{array}{l}\text { Value } \\
\text { traded } \\
\text { ratio } \\
(\mathrm{TVMS})^{\star *} \\
(6=5 / 3)\end{array}$ & $\begin{array}{l}\text { Turnover ratio } \\
(\text { TOR) })^{\star *} \\
(7=5 / 2)\end{array}$ & $\begin{array}{l}\text { All-share } \\
\text { Index(8) }\end{array}$ & $\begin{array}{l}\% \Delta \mathrm{ASI}^{* *} \\
\text { (9) }\end{array}$ \\
\hline 1991 & 12.2 & 23.13 & 329.071 & 0.07 & 0.172 & 0.00052 & 0.00744 & 783 & 0 \\
\hline 1992 & 44.6 & 31.27 & 555.446 & 0.056 & 0.262 & 0.00047 & 0.00838 & 1107.6 & 0.29 \\
\hline 1993 & 57.1 & 47.44 & 715.242 & 0.066 & 0.473 & 0.00061 & 0.00997 & 1543.8 & 0.28 \\
\hline 1994 & 57.4 & 66.37 & 945.557 & 0.07 & 0.524 & 0.00055 & 0.0079 & 2205 & 0.3 \\
\hline 1995 & 72.7 & 180.31 & 2008.56 & 0.09 & 0.397 & 0.0002 & 0.0022 & 5092.2 & 0.57 \\
\hline 1996 & 29.3 & 285.82 & 2799.04 & 0.102 & 0.882 & 0.00032 & 0.00309 & 6992.1 & 0.27 \\
\hline 1997 & 10.7 & 281.96 & 2906.63 & 0.097 & 13.3 & 0.00458 & 0.04717 & 20128.9 & 0.65 \\
\hline 1998 & 7.9 & 262.52 & 2816.41 & 0.093 & 2.1 & 0.00075 & 0.00799 & 5672.8 & -2.55 \\
\hline 1999 & 6.6 & 300 & 3312.24 & 0.091 & 3.9 & 0.00118 & 0.013 & 5266.4 & -0.08 \\
\hline 2000 & 6.9 & 478.6 & 4717.33 & 0.102 & 5 & 0.00106 & 0.01045 & 8111 & 0.35 \\
\hline 2001 & 18.9 & 662.6 & 4909.53 & 0.135 & 5.9 & 0.0012 & 0.0089 & 10963.1 & 0.26 \\
\hline 2002 & 12.9 & 763.9 & 7128.2 & 0.107 & 6.6 & 0.00093 & 0.00864 & 12137.7 & 0.1 \\
\hline 2003 & 14 & 1356 & 8742.65 & 0.155 & 13.3 & 0.00152 & 0.00981 & 14565.45 & 0.17 \\
\hline 2004 & 15 & 2112.5 & 11673.6 & 0.181 & 19.21 & 0.00165 & 0.00909 & 23844.5 & 0.39 \\
\hline 2005 & 17.9 & 2900.1 & 14735.32 & 0.197 & 26.7 & 0.00181 & 0.00921 & 24085.8 & 0.01 \\
\hline 2006 & 8.2 & 5121 & 18709.79 & 0.274 & 36.7 & 0.00196 & 0.00717 & 33189.3 & 0.27 \\
\hline 2007 & 5.4 & 13295 & 20874.17 & 0.637 & 138.1 & 0.00662 & 0.01039 & 57990.2 & 0.43 \\
\hline 2008 & 11.6 & 9560 & 24552.78 & 0.389 & 193.14 & 0.00787 & 0.0202 & 31450.8 & -0.84 \\
\hline 2009 & 12.5 & 7030 & 25102.94 & 0.28 & 102.85 & 0.0041 & 0.01463 & 20827.2 & -0.51 \\
\hline 2010 & 13.7 & 9920 & 32311.3 & 0.307 & 93.3 & 0.00289 & 0.09405 & 24727.8 & 0.16 \\
\hline
\end{tabular}

Sources : CBN statistical bulletin \& NSE factbook

${ }^{* *}$ Authors' computation

Table 1:

Summary of Regression result

\begin{tabular}{|l|c|c|}
\hline \multicolumn{1}{|c|}{ Variables } & Coefficient & t-statistic \\
\hline Constant & 0.241 & 5.296 \\
INF & -0.003 & -1.912 \\
& & \\
\hline
\end{tabular}

Adjusted $r^{2}=0.123, t_{c a l}==5.296, t_{t a b}=1.729,5 \%$ level of significance 
The result reveals that INF is responsible for $12.3 \%$ variation in MCAGDP (market capitalization ratio) of the Nigerian stock market. The adjusted $r^{2}$ coefficient 0.123 (coefficient of determination) indicates that INF accounted for $12.3 \%$ of the variation in the influence on MCAGDP of the stock market.

The $t_{\text {cal }}==5.296>t_{\text {tab }}=1.729$, which means that the assumption that there is no negative statistical association between MCAGDP and INF is rejected. Thus:

MCAGDP $=0.241-0.003 \mathrm{INF}$

The explanatory variable coefficient (coefficient of INF) is correctly(theoretical expected) signed at $5 \%$ level of significance. There is a negative correlation of -0.411 between MCAGDP and INF. This aligns with a priori expectation. Hence, the model is correctly specified and statistically significant at $5 \%$ significant level.

Model 2:

$$
\text { TVMS }=\beta_{0}+\beta_{1} I N F+e
$$

Table 2:

Summary of Regression result

\begin{tabular}{|l|c|c|}
\hline \multicolumn{1}{|c|}{ Variables } & Coefficient & t-statistic \\
\hline Constant & 3.071 & 4.595 \\
INF & -0.047 & -2.063 \\
& & \\
\hline
\end{tabular}

Adjusted $\mathrm{r}^{2}=0.146, \mathrm{t}_{\mathrm{cal}}==4.595, \mathrm{t}_{\mathrm{tab}}=1.729,5 \%$ level of significance

The result reveals that INF is responsible for $14.6 \%$ variation in TVMS (total value traded ratio) of the Nigerian stock market. The adjusted $r^{2}$ coefficient 0.146 (coefficient of determination) indicates that INF accounted for $14.6 \%$ of the variation in the influence on TVMS of the stock market.

The $t_{\text {cal }}==4.595>t_{\text {tab }}=1.729$, which means that the assumption that there is no negative statistical association between TVMS and INF is rejected. Thus:

TVMS $=2.071-0.047 \mathrm{INF}$

The explanatory variable coefficient (coefficient of INF) is correctly (theoretical expected) signed at $5 \%$ level of significance. There is a negative correlation of -0.437 between TVMS and INF. This aligns with a priori expectation. Hence, the model is correctly specified and statistically significant at $5 \%$ significant level.

Model 3:

$$
\% \Delta \text { ASI. }=\theta_{0}+\theta_{1} \text { INF }+y
$$

Table 3:

Summary of Regression result

\begin{tabular}{|l|c|c|}
\hline \multicolumn{1}{|c|}{ Variables } & Coefficient & t-statistic \\
\hline Constant & 20.564 & 2.948 \\
INF & -0.233 & -0.974 \\
& & \\
\hline
\end{tabular}

Adjusted $r^{2}=0.003, t_{c a l}==2.948, t_{\text {tab }}=1.729,5 \%$ level of significance

The result reveals that INF is responsible for only $0.3 \%$ variation in $\% \Delta \mathrm{ASI}$ (percentage change in Allshare Index) of the Nigerian stock market. The adjusted $r^{2}$ coefficient 0.003 (coefficient of determination) indicates that INF accounted for $0.3 \%$ of the variation in the influence on $\% \Delta A S I$ of the stock market. This low value of $R^{2}$ is as a result of the diversity of the cross-sectional units.

The $t_{\text {cal }}==2.948>t_{\text {tab }}=1.729$, which means that the assumption that there is no negative statistical association between \% $\mathrm{ASSI}$ and INF is rejected. Thus the estimated regression model is:

$\% \Delta \mathrm{ASI}=20.564-0.233 \mathrm{INF}$

The explanatory variable coefficient (coefficient of INF) is correctly (theoretical expected) signed at 5\% level of significance. There is a negative correlation of -0.224 between $\% \Delta \mathrm{ASI}$ and INF. This aligns with a priori expectation. Hence, the model is correctly specified and statistically significant at $5 \%$ significant level.

\section{Model 4:}

$$
\text { TOR }=\rho_{0}+\rho_{1} \text { INF }+\varepsilon
$$

Table 4:

Summary of Regression result

\begin{tabular}{|l|c|c|}
\hline \multicolumn{1}{|c|}{ Variables } & Coefficient & t-statistic \\
\hline Constant & -0.202 & -0.878 \\
INF & 0.10 & 1.325 \\
& & \\
\hline
\end{tabular}


Adjusted $r^{2}=0.038, t_{c a l}==-0.878, t_{\text {tab }}=1.729,5 \%$ level of significance

The result shows that INF is responsible for $3.8 \%$ variation in TOR (turnover ratio) of the Nigerian stock market. The adjusted $r^{2}$ coefficient 0.038 (coefficient of determination) indicates that INF accounted for 3.8 $\%$ of the variation in the influence on TOR of the stock market.

The $t_{c a l}==-0.878<t_{\text {tab }}=1.729$, which means that the assumption that there is no negative statistical association between TOR and INF is accepted. Thus the estimated regression model is:

$$
\text { TOR }=-0.202+0.10 \mathrm{INF}
$$

There is a positive correlation of 0.298 between TOR and INF. This shows a divergence from a priori expectation. Hence, the model is statistically insignificant at $5 \%$ significant level.

\section{SUMMARY AND CONCLUSIONS}

Inflation rates in Nigeria have persistently been twodigits and considering its impact on the performance of the stock market informed the need for this paper. The paper presents preliminary evidence of the influence of inflation (INF) on measures of stock market performance; market capitalization ratio (MCAGDP), total value of shares traded ratio (TVMS), turnover ratio (TOR), and percentage change in All-share Index (\% $\% \mathrm{ASI})$ for a 20-year period (1991-2010).

Evaluation of the impact of inflation on the various measures show that the greatest influence of $14.6 \%$ is on TVMS while the least is on $\% \Delta \mathrm{ASI}$ of $0.3 \%$ variation. This shows that the effect of inflation on performance of Nigerian stock market is weak. All the measures show a negative relationship to inflation except TOR which showed a divergence from a priori expectation as revealed by the positive correlation between inflation and the turnover ratio.

A look at the Table 1A (Appendix A) reveals that 2004- 2007 was period of peak of activities in the Nigerian stock market. However, inflation accounts for just $3.8 \%$ influence on turnover ratio. These low levels of influence of inflation on measures of stock market performance show that investments in the market are regarded as a good hedge against inflation in Nigeria.

Considering the importance of the stock market to economic development, the Securities and Exchange Commission (SEC) and the Nigerian Stock Exchange (NSE) should strive to improve on market capitalization of the stock market by attracting listing and increased trading activities. The present state of the Nigerian stock market is not unconnected with low literacy level and poor corporate governance issues.

The issue of public enlightenment to encourage investment and transactions in stock should be given attention; while appropriate corporate governance framework should be put in place and enforced for a restoration of confidence in the market. The problem of double digits inflation rate should be tackled. The Central Bank of Nigeria (CBN) should formulate and use policy instruments that will maintain inflation at a reasonably low level so that it will not erode the real value of stock gains.

\section{REFERENCES}

Alile, H. (1997). Government must Divest. The Business Concord of Nigeria 2nd December, p8.

Barro, R. J. (1995). Inflation and Economic Growth. Bank of England Bulletin (May), pp 166-176.

Boyd, J. H; Levine, R. and Smith, B. D. (1996). Inflation and Financial market performance. Working paper 537D, Federal Reserve Bank of Minneapolis Research Department.

Bruno, M. and Easterly, W. (1995). Inflation crises and long-run growth. Policy Research Department Manuscript, Washington DC: World Bank.

Caban, O. L. (2008). Effects of Inflation on the Stock Market. Retrieved from http://ezinnearticles.com on 4/9/2010.

Corrado, C.J. and Jordan, B. D. (2002). The Fundamentals of Investments Valuation and Management. 2nd ed USA, McGraw-Hill Companies Inc.

Daferighe, E. E. and Aje, S. O. (2009). An Impact Analysis of Real Gross Domestic Product, Inflation and Interest rates on stock prices of quoted companies in Nigeria. International Research Journal of Finance and Economics, Issue 25, pp 53-63.

DeGregorio, J. (1992). The effects of Inflation on Economic Growth. European Economic Review, 36(2-3), pp 417-424.

Demirguc-Kunt, A. and Levine, R. (1996). Stock market, Corporate finance and Economic Growth: An overview. World Bank Economic Review, 19 (May) pp 223-240.

Emenuga, C. (1998). Nigerian Capital Market and Nigeria Economic Performance at a one day seminar organized by Nigerian Economic Society at the Institute of International Affairs, Lagos, (January). 
Engle, R. F. and Rangel. J. G. (2005). The Spline GARCH Model for Unconditional Volatility and its Global Macroeconomic causes. Econometica, 50, pp 9871007.

Fischer, S. (1993). The role of macroeconomic factors in growth. Journal of Monetary Economics, 32 (Dec), pp 485-511.

Gerolamo,D. (2001). Inflation and its effects on Investment. Retrieved from http:// econ10.bu.edu/Ee341_money/papers/Geramo_pape r.htm on $1 / 9 / 2010$.

Gottlieb, C. (2010). On the Distributive Effects of Inflation. Retrieved from http://editoralexpress.com/cgibin/conference/ on 10/9/2010.

Hamilton, A. (2005)._Effects of Inflation on your Investment Portfolio.Retrieved

from http://www.zealllc.com/2005/stockinf.htm on $5 / 9 / 2010$

Hellerstein, R. (1997). The Impact of Inflation. Federal Reserve Bank of Boston Regional Review. Retrieved from http:// www. bos.frb.org/economic /nerr/rr/997 /winter/hell971.htm on 1/9/2010.

Kithinji, A. and Ngugi, W. (2009). Stock Market Performnace before and after General elections - A case study of the Nairobi Stock Exchange. Retrieved from http:// webcache.goggleusercontent.com on 5/9/2010.

Levine, R. and Zervos, S. (1996). Stock market, Banks and Economic Growth. American Economic Review, 88 (3) pp 537-558.
Nyong, M. O. (1997). Capital market development and long-run Economic Growth: Theory, Evidence and Analysis. First Bank Review, Dec. pp 13-38.

Obadan, M. I. (1998). Internationalization of the Nigerian Capital Market in Proceedings of Nigerian Economic Society at a one day seminar held at the Nigerian Institute of International Affairs, Lagos, (January).

Onagoruwa, O. (2006). Analysis propose Antitodes to Down Trend in the market. Stock Watch, Vol. 1 (4), pp 3-8.

Onosede, G. O. (1998). The Capital Market and Nigeria's Economic Development at a one day seminar organized by Nigerian Economic Society at the Institute of International Affairs, Lagos, (January).

Osinubi, T. S. (1998). Stock Market Development and Long-run Growth in Nigeria. Unpublished M.Sc. Economics Dissertation, University of Ibadan, Nigeria.

Oyejide, T. A. (1994). The Financial System and Economic Growth in the context of political transition. Central Bank of Nigeria Economic and Financial Review, Vol. 32 (3) pp 260- 267.

Reilly, F. and Brown, C. (1997). Investment Analysis and Portfolio Management. 5th ed., New Jersey: Prentice Hill Inc.

Skousen, M. (2006) Inflation and its effects in the stock market. Retrieved from

http://webcache.googleusercontent.com on 5/9/2010. 